\title{
EUHTE3E
}

2019, бр. 16, стр. 01-12.

UDK 37.064 .2

Original scientific paper

37.018 .3

doi:10.5937/sinteze8-24739

\section{TEACHER COMMUNICATION QUALITY WITH STUDENTS IN BOARDING SCHOOLS}

\author{
Nedeljko M. Milanović ${ }^{1}$
}

\begin{abstract}
The article presents the results of an empirical research aimed at understanding students' attitudes toward the communication they have with a teacher in a boarding school. The study was conducted on a sample of 67 subjects, 36 female and 31 male. For the purposes of this research, a descriptive method - a survey technique - was used. The analyzed results of the research show that the majority of students feel comfortable and relaxed in communication with the teacher. According to the students, communication in boarding schools can be improved by organizing workshops on verbal and non-verbal communication, greater commitment of teachers to communication with students and having more time and patience to listen to students. The results of the study show that students believe that teachers possess valid verbal and non-verbal communication skills and that teachers have more democratic communication than autocratic ones. To make the life and daily functioning of the students in the boarding school positive and effective, it is also necessary that the communication on the teacher-student relationship be of a good quality, healthy and successful.
\end{abstract}

Keywords: communication, teacher, student, boarding school.

\section{INTRODUCTION}

When it comes to the quality of communication in boarding schools, contemporary literature cannot praise with many theoretical and empirical works engaged in the research and improvement of communication between the teacher and the student. Boarding schools are ,educational institutions where students are provided with conditions for learning and learning assistance, they are provided with accommodation, food, cultural and

\footnotetext{
${ }^{1}$ nedeljko996@gmail.com,. University of Kragujevac, Faculty of Education in Jagodina, Master student
} 
leisure activities, physical recreation and other common needs" (Ješić, 2008: 20). Therefore, boarding school should provide students with positive, undisturbed and healthy psychophysical growth and development.

In various literatures we encounter many definitions of communication. "Communication is the process by which something seems common, connecting to a community and communicating among themselves" (Ivanek, Mikić, et al., 2012: 65). Author Koković points out that communication is "a form of verbal and non-verbal communication, interactions on the symbolic plan, exchange of information between people using signs and symbols" (Koković, 1997: 217). Communication can be defined as the process of interaction between individuals or groups, and by mediating words, images, movements, symbols or signs (JašinMojse, 2006). Considering communication in different definitions, we can most easily define it as the process of exchanging, transmitting messages.

As this article deals with communication in boarding schools and places emphasis on the main actors in the educational work, the question is what is pedagogical communication? By Suzić ,pedagogical communication, means transmitting, communicating, exhibiting, receiving, in a word, messaging as well as establishing relationships, communication, means and manner of communication among participants in the educational and learning process" (Suzić, 2005: 167-168). How we define communication as the process of exchanging, transmitting messages, we can most easily define pedagogical communication as the exchange of messages between the main actors (teachers and students) in the educational work. The education process relies almost entirely on communication. Communication significantly helps to build relationships and facilitates the achievement of goals (Akonnubi, Gbadeyan, et al., 2012). Without quality communication, there is no effective and successful educational work in boarding schools.

In order for the teacher-student communication to be of a good quality, it is necessary to include the following: "communication freedom, communication vulnerability, tolerance and social sensitivity, acquiring and practicing internal control, communication literacy, togetherness, cooperation, understanding and respect for others, ability to empathize, to appreciate differences" (Zrilić, 2010: 231). Teachers are expected to master all communication skills and apply them daily in working with students. 
When talking about communication styles in educational work in the pedagogical and psychological literature of numerous classifications, but most commonly used are the two dominant ones: the autocratic and democratic style of communication.

The autocratic style of communication is characterized by austerity towards students, punishment, disrespect for the student's personality, distance, lack of empathy, as well as rigidity in work and relationship with students. This kind of communication from the teacher to the students has a negative effect and causes fear, obedience, humility, while some students may also respond by rebelliousness (Milovanović, 2010). This kind of teacher independently sets the rules, uses complicated and complex terms in communication with students, does not involve students in decision making and communication is based on commands and requests.

Contrary to autocratic style, democratic style ,, is characterized by communication flowing in different directions - upstream (from student to teacher), downstream (from teacher to student) and horizontally - from student to student" (Ješić, 2008: 204). A teacher who cultivates a democratic style of communication when working with students is tolerant, empathetic, calmly accepts students' mistakes, helps students find the right solution for them, encourages cooperativeness, respects the individual characteristics of all students. Teachers must possess certain competencies to work in educational institutions. The most important competence is communication (Yesil, 2006). Communication competent teacher is a teacher who is emotionally and socially expressive as a person, sensitive and controlled (Milovanović, 2010). In order for the teacher to be successful in teaching, it is essential that communication with students is positive, effective and two-way. "In two-way communication, the interlocutors respond to one another and reciprocally influence one another. Both talk, and both change. From such a conversation, all the interlocutors come out different. At the beginning and end of the conversation, they are no longer the same. It is a conversation in which one hears, thinks and speaks "(Brajša, 1993: 22).

Communication is the primary tool of any teaching staff. Therefore, boarding school teachers must master all communication skills, because positive and successful educational work is achieved through valid, quality and two-way communication. 


\section{RESEARCH METHODOLOGY}

The subject of the research is the communication of teachers with students in secondary boarding schools.

The aim of the research is to understand the students' relationship to the communication they have with the teacher in the boarding school.

From a defined research goal the following tasks occur:

- Determine how often students have individual conversations with the teacher.

- Investigate whether there is a statistically significant difference between students regarding whether they turn to a teacher when they have a particular gender problem.

- Investigate whether students turn to a teacher when they have a problem.

- Analyze the degree of disagreement of the student according to the teacher's communication skills.

- Investigate how students feel when talking to a teacher.

- Determine how often the teacher is democratic and how autocratic is in communicating with students.

- Examine how in the opinion of the students communication between the teacher and the student can be improved.

Research hypothesis

The general hypothesis of the research emerges from this goal:

It is assumed that students have a positive attitude towards the communication that teachers have with them in boarding schools.

The following research hypotheses emerge from the formulated tasks:

- It is assumed that students often have individual conversations with the teacher.

- It is assumed that there is no statistically significant difference between the students as to whether they turn to the teacher when they have a particular gender problem.

- It is assumed that students assess that there are positive communication skills in the teacher.

- It is assumed that students feel comfortable communicating with the teacher.

- It is assumed that there is a more democratic style in the communication of the teacher with the students.

- It is assumed that teacher-student communication can be enhanced by organizing workshops on verbal and non-verbal communication. 
The descriptive method and the survey technique were used for the purposes of the survey. From non-parametric methods we used: determination of basic statistical indicators (frequencies, percentages); calculation of scale value index (ISV) in a Likert-type assessment scale; $\chi 2$ test, to determine if there are statistically significant differences between the variables.

The questionnaire was constructed as a separate instrument for this empirical research. The questions in the questionnaire are of open, combined and closed type (with pre-offered response modalities). The questionnaire consists of two complete questions: the first two questions relate to general sample data, while the second part of the questionnaire concerned information about the problem being investigated.

Population and research sample

The study population consisted of secondary boarding school students in Jagodina and Negotin. A total of 67 students, aged 15 to 18, participated.

Based on the questionnaire, data on the gender of respondents were obtained, where $46,3 \%(\mathrm{f}=31)$ are male and $53,7 \%(\mathrm{f}=36)$ are female.

$31,3 \%(\mathrm{f}=21)$ of the first grade students participated in the survey, $20,9 \%(\mathrm{f}=14)$ of second grade students, $25,4 \%(\mathrm{f}=17)$ of third grade students and $22,4 \%(\mathrm{f}=15)$ of fourth-year high school students placed in the boarding school.

\section{RESEARCH RESULTS}

Our first research task was to determine how often students have individual conversations with the teacher.

Chart 1. How often students and teachers conduct individual conversations.

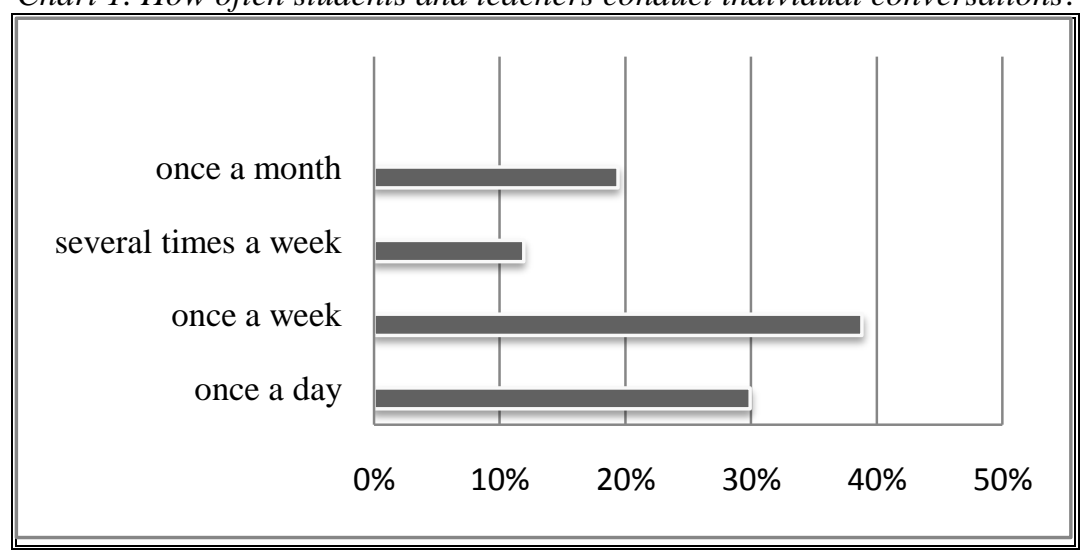


From the results shown in Chart 1 , we can see that $19,4 \%(\mathrm{f}=13)$ of the students indicated that they have individual conversations with the teacher once a month, $11,9 \%(\mathrm{f}=8)$ cited several times a week, 38,8\% $(\mathrm{f}=26)$ of students responded once a week and $29,9 \% \quad(\mathrm{f}=20)$ of the students reported having a conversation with the teacher once a day. By asking this question, we wanted to see how well teachers really care about their students. Individual conversation involves one student and one teacher. During these conversations, students can present their problems, difficulties, ideas, attitudes, opinions, and speak more freely with the teacher, than they will do in front of an educational group. This method of communication has its strengths and advantages, such as improving student motivation, self-esteem, real-world understanding of students' abilities and most importantly contributing to the development of trust in teacher (Ješić, 2008). Therefore, the results analyzed show that boarding school teachers often have individual conversations with their students.

The next task of our research was to investigate whether there was a statistically significant difference between students regarding whether or not they contact the teacher when they have a particular problem considering gender.

The chi-square indicates that the difference in response frequency is statistically significant $(\chi 2=14,064 ; \mathrm{df}=1 ; \mathrm{p}=0,00)$ between male and female students who said yes, 59,7\% $(\mathrm{f}=40)$ and $40,3 \%(\mathrm{f}=27)$ who do not turn to the teacher when they have a problem.

Chart 2. Structure of students' gender responses, whether they approach

the teacher when they have a problem.

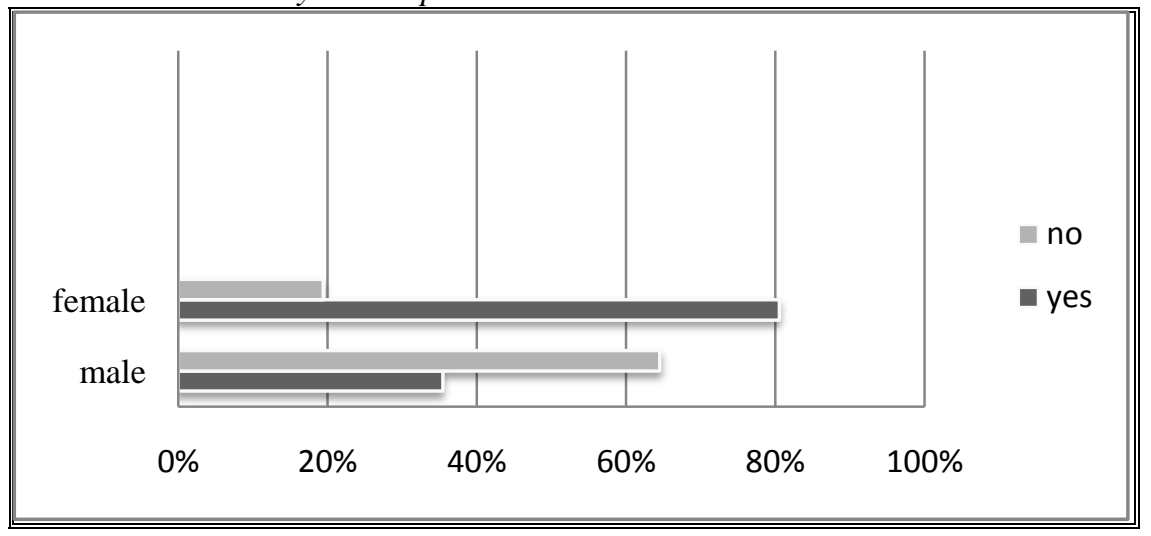


The results shown in Chart 2 show that 80,56\% ( $\mathrm{f}=29$ ) of female students and $35,48 \%(\mathrm{f}=11)$ of male students turn to a teacher when they have a problem, until $19,44 \%(\mathrm{f}=7$ ) female students and $64,52 \%(\mathrm{f}=20)$ male students don't turn for help and advice. So, female students are more likely to turn to a teacher for help or advice when they encounter a problem, than male students. Analyzed research results (Sarı, Ötünç, et al., 2007) indicate that female students have better developed communication skills than male students. Female students are more willing to share their problem with the teacher and find the best solution with him.

Students were asked if they did not approach the teacher when they had a problem to give reasons why this is so. The question was openended and we divided the answers into four groups. $9 \%(\mathrm{f}=6)$ of students answered not to contact the teacher when they have a problem, because it fears the teacher's reaction. $11,9 \%(\mathrm{f}=8)$ of the students cited the teachers' disinterest as a reason, $3 \%(\mathrm{f}=2)$ of students said they did not want to upset their teacher with their problems, while $16,4 \%(\mathrm{f}=11)$ of the students answered that the teacher never had time to talk.

With the research we wanted to check the degree of disagreement of students with the communication skills of the teacher. Table 1 lists the response frequencies - the degree of agreement with the subjects' testimonials, expressed on a Likert-type assessment scale.

Table1. Student consent to testify, expressed on a Likert scale of assessment.

\begin{tabular}{|c|c|c|c|c|c|c|c|c|c|c|c|}
\hline \multirow{2}{*}{$\begin{array}{l}\text { Claims on teacher- } \\
\text { student } \\
\text { communication }\end{array}$} & \multicolumn{2}{|c|}{$\begin{array}{c}\text { I totally } \\
\text { agree }\end{array}$} & \multicolumn{2}{|c|}{ I agree } & \multicolumn{2}{|c|}{$\begin{array}{c}\text { I'm } \\
\text { undecided }\end{array}$} & \multicolumn{2}{|c|}{ I disagree } & \multicolumn{2}{|c|}{$\begin{array}{l}\text { I totally } \\
\text { disagree }\end{array}$} & \multirow{2}{*}{ ISV } \\
\hline & $\mathrm{f}$ & $\%$ & $f$ & $\%$ & $\mathrm{f}$ & $\%$ & $f$ & $\%$ & $\mathrm{f}$ & $\%$ & \\
\hline $\begin{array}{c}\text { During the } \\
\text { conversation, the } \\
\text { teacher looks me in } \\
\text { the eye. }\end{array}$ & 25 & 37,3 & 33 & 49,2 & - & - & 9 & 13,4 & - & - & 4,10 \\
\hline $\begin{array}{l}\text { The teacher speaks } \\
\text { in understandable } \\
\text { and clear language. }\end{array}$ & 22 & 32,8 & 36 & 53,8 & - & - & 9 & 13,4 & - & - & 4,06 \\
\hline $\begin{array}{l}\text { The information } \\
\text { that teacher gives } \\
\text { me is always clear } \\
\text { and concrete. }\end{array}$ & 33 & 49,3 & 24 & 35,8 & 8 & 11,9 & 2 & 3 & - & - & 4,31 \\
\hline $\begin{array}{l}\text { The teacher does } \\
\text { not interrupt me } \\
\text { while I speak. }\end{array}$ & 17 & 25,4 & 28 & 41,8 & 5 & 7,5 & 17 & 25,4 & - & - & 3,67 \\
\hline $\begin{array}{l}\text { As I speak, the } \\
\text { teacher listens } \\
\text { carefully to me. }\end{array}$ & 26 & 38,8 & 29 & 43,4 & - & - & 12 & 17,9 & - & - & 4,03 \\
\hline $\begin{array}{c}\text { The teacher allows } \\
\text { us to express our } \\
\text { opinion. }\end{array}$ & 13 & 19,4 & 20 & 29,9 & 6 & 9 & 19 & 28,4 & 9 & 13,4 & 3,13 \\
\hline
\end{tabular}


Based on the results presented in Table 1, we can see that students generally have a positive attitude towards the present skills of the teacher in communicating with them. From the presented results we conclude that teachers coordinate and adequately apply both verbal and non-verbal communication. Therefore, students find that teachers generally possess the valid skills needed to work in educational work. On the item that the teacher allows students to express their opinions a lower scale value index was calculated relative to the other claims in Table 1. Similar results were obtained by research (Jovanović, 2009), in which students stated that the class lacked freedom of expression. The results of the research (Pejić, 2006) show that interrupting students' answers is one of the most pronounced phenomena that impairs the quality of communication in teaching.

The next research task was to explore how students feel in communicating with a teacher.

Table 2. How students feel in communicating with the teacher.

\begin{tabular}{|c|c|c|c|c|c|c|c|c|c|c|c|}
\hline \multirow{2}{*}{$\begin{array}{l}\text { During the } \\
\text { conversation } \\
\text { with the } \\
\text { teacher I feel: }\end{array}$} & \multicolumn{2}{|c|}{$\overline{\text { Very often }}$} & \multicolumn{2}{|c|}{$\overline{\text { Often }}$} & \multicolumn{2}{|c|}{ Periodically } & \multicolumn{2}{|c|}{ Rarely } & \multicolumn{2}{|c|}{ Never } & \multirow{2}{*}{ ISV } \\
\hline & f & $\%$ & f & $\%$ & $\mathrm{f}$ & $\%$ & $\mathrm{f}$ & $\%$ & f & $\%$ & \\
\hline Pleasantness & 28 & 41,8 & 27 & 40,3 & 2 & 3 & 7 & 10,4 & 3 & 4,5 & 4,04 \\
\hline Relaxation & 39 & 58,3 & 15 & 22,4 & 10 & 14,9 & 3 & 4,5 & - & - & 4,34 \\
\hline Fear & 8 & 11,9 & 12 & 17,9 & 9 & 13,4 & 10 & 14,9 & 28 & 41,8 & 2,43 \\
\hline
\end{tabular}

From the results presented in Table 2, we can see that the majority of students feel comfortable (ISV=4,04) and relaxed (ISV=4,34) in communication with the teacher. The lowest index of the scale value 2.43 indicates the presence of fear in the student in communication with the teacher. To students who responded that they very often, often and occasionally, feel fear in communicating with the teacher, the question was asked to state what the reasons for such feelings were. The question was open-ended and the answers received were classified into three categories. 14,9\% $(\mathrm{f}=10)$ of the students indicated that they felt apprehensive about the authoritarian style of the teacher. An autocratic educator creates an atmosphere of fear, sometimes using a method of punishment in dealing with students and traits that appreciate are obedience and unconditional performance of tasks (Milošević, 2015). $10,4 \%(\mathrm{f}=7)$ of the students answered that the teacher did not want to listen to them fully and reached conclusions very quickly, not fully aware of the situation, while $17,9 \%(\mathrm{f}=12)$ of the students indicated that they did 
not trust the teacher. Trust is a long process and is gained over time. In order for a quality life in boarding school, it is necessary for the teacher to pay attention to establishing trust, and this implies an teachers' interest and commitment to his students.

Table 3. Democratic and autocratic communication of teachers with students.

\begin{tabular}{|c|c|c|c|c|c|c|c|c|c|c||}
\hline \multirow{2}{*}{} & \multicolumn{2}{|c|}{ Very often } & \multicolumn{2}{|c|}{ Often } & \multicolumn{2}{c|}{ Periodically } & \multicolumn{2}{c|}{ Rarely } & \multicolumn{2}{c|}{ Never } \\
\cline { 2 - 10 } & $\mathrm{f}$ & $\%$ & $\mathrm{f}$ & $\%$ & $\mathrm{f}$ & $\%$ & $\mathrm{f}$ & $\%$ & $\mathrm{f}$ & $\%$ \\
\hline $\begin{array}{c}\text { The teacher is tolerant } \\
\text { in communication. }\end{array}$ & 17 & 25,4 & 25 & 37,3 & 14 & 20,9 & 10 & 14,9 & 1 & 1,5 \\
\hline $\begin{array}{c}\text { The teacher calmly } \\
\text { accepts all our mistakes. }\end{array}$ & 20 & 29,9 & 32 & 47,8 & 3 & 4,5 & 7 & 10,4 & 5 & 7,5 \\
\hline $\begin{array}{c}\text { The teacher treats all } \\
\text { students with respect. }\end{array}$ & 11 & 16,4 & 34 & 50,7 & 10 & 14,9 & 12 & 17,9 & - & - \\
\hline $\begin{array}{c}\text { The teacher uses } \\
\text { complicated words that } \\
\text { students do not } \\
\text { understand. }\end{array}$ & - & - & - & - & - & - & 4 & 6 & 63 & 94 \\
\hline $\begin{array}{c}\text { The teacher himself } \\
\text { makes the decisions and } \\
\text { sets the rules, does not } \\
\text { agree with the students. }\end{array}$ & - & - & 2 & 3 & 4 & 6 & 8 & 11,9 & 53 & 79,1 \\
\hline
\end{tabular}

Based on the results presented in Table 3, we conclude that, in the opinion of the students surveyed, the democratic style of communication in boarding school is more prevalent. Therefore, a democratically oriented teacher is tolerant in communication with students, respects their personality, directs, encourages and motivates students in their work. So, the democratic style of the teacher is determined to be successful and positive in the educational work.

At the end of this research, we wanted to examine how, in the student's view, communication between teacher and student can be improved.

Table 4. Student suggestions for improving communication with the teacher.

\begin{tabular}{|c|c|c|c|}
\hline & $\begin{array}{c}\text { Organization of workshops } \\
\text { on verbal and non-verbal } \\
\text { communication }\end{array}$ & $\begin{array}{c}\text { Higher commitment of teachers to } \\
\text { communication with students }\end{array}$ & $\begin{array}{c}\text { More patience and time on } \\
\text { the part of educators to listen } \\
\text { to students }\end{array}$ \\
\hline $\mathrm{f}$ & 18 & 25 & 24 \\
\hline$\%$ & 26,9 & 37,3 & 35,8 \\
\hline
\end{tabular}

Based on the results presented in Table 4, we can conclude that the students thoroughly approached the answer to the question about improving communication between teachers and students. 26,9\% ( $\mathrm{f}=18)$ of the students indicated that communication in boarding school could be improved by organizing workshops on verbal and non-verbal 
communication, $37,3 \% \quad(\mathrm{f}=25)$ of students believe that a greater commitment of the teacher to communication with students can improve the communication process, while $35,8 \%(\mathrm{f}=24)$ of students indicated that communication can be improved by having more patience and time by teachers to listen to students.

Teachers need to improve their communication skills, because they are models to their students from which they will learn and acquire knowledge and abilities and thus interact and communicate with others.

\section{CONCLUSIONS}

In this research, an attempt was made to look at and present the students' relationship to the communication they have with the teacher in boarding school.

The analyzed results show that students often have individual conversations with the teacher and that female students are more likely to turn to the teacher for help when they have a problem. The majority of respondents stated that they feel comfortable and relaxed during their communication with the teacher, while a third of respondents said that they very often and often feel fear. Autocratic communication of the teacher, reaching a conclusion very quickly and distrust in the teacher are the main reasons that cause fear in communication with the educator.

When it comes to enhancing teacher-student communication, respondents answered that the communication process can be improved by organizing and conducting workshops that will address both verbal and non-verbal communication, that it is necessary for teachers to become more committed to communicating with students and to have more patience and time to listen to them.

The general conclusion we can draw from the whole research is that students expressed a high degree of agreement with the communication skills of the teacher, suggesting that teachers appropriately apply and coordinate verbal and non-verbal communication. Students have a positive attitude towards the communication the teacher achieves with them and point out that the democratic style of communication is more dominant than autocratic.

We believe this topic provides many opportunities for enhancing communication in boarding school, as well as for further research that could focus on more detailed research, with a larger number of respondents, on the representation of verbal and nonverbal, direct and indirect, as well as violent and nonviolent teacher-student communication. 
Akinnubi, O. P., Gbadeyan, C. O., Fashiku, C. O., \& Kayode, D. J. (2012). Effective Communication: A Tool for Improvement of Secondary School Management. Journal of Education and Practice, 3(7), 105-110.

Brajša, P. (1993). Pedagoška komunikologija: Razgovor, problemi $i$ konflikti u školi. Školske novine.

http://library.foi.hr/lib/knjiga.php?B=20\&sqlx=3296\&H=

Ivanek, P., Mikić, B., \& Karabašić, J. (2012). Razredna klima kao faktor sukoba u komunikaciji između učenika i nastavnika. Sportske nauke i zdravlje, 2(1), 65-74. doi: 10.7251/SSH1201059I

Jašin-Mojse, T. (2006). Komunikacija u učionici. Jagodina: Zbornik radova, međunarodna naučna konferencija, Jagodina, Pedagoški fakultet u Jagodini i Filološko-umetnički fakultet u Kragujevcu, 386-395.

Ješić, D. (2008). Domska pedagogija. Jagodina: Učiteljski fakultet.

Jovanović, M. (2009). O postojećoj komunikaciji u nastavi i o neophodnim promenama. Nastava i vaspitanje, 58(2), 201-215.

Koković, D. (1997). Pukotine kulture. Beograd: Prosveta.

Milovanović, R. (2010). Interakcija i komunikacija u vaspitnom radu. Jagodina: Pedagoški fakultet.

Milošević, A. (2009). Stilovi rada savremenog nastavnika. Užice: Regionalni centar za profesionalni razvoj zaposlenih u obrazovanju.

Pejić, R. (2006). Činioci koji otežavaju kvalitet komunikacije u nastavi. Jagodina: Zbornik radova, međunarodna naučna konferencija, Jagodina, Pedagoški fakultet u Jagodini i Filološko-umetnički fakultet u Kragujevcu, 277-285.

Sar1, M., Ötünç, E., \& Erceylan, H. (2007). Quality of Life in High Schools: The Case of Adana Province. Educational Administration: Theory and Practice, 13(2), 297-320.

Suzić, N. (2005). Pedagogija za XXI vijek. Banja Luka: TT-centar.

Yesil, R. (2006). Teaching proficiencies of social studies teachers in class (the sample of Kirşehir). Kırşehir Eğitim Fakültesi Dergisi (KEFAD), 7(2), 61-78.

Zrilić, S. (2010). Kvaliteta komunikacije i socijalni odnosi u razredu.Pedagogijska istraživanja, 7(2), 231-241. 
12

\title{
КВАЛИТЕТ КОМУНИКАЦИЈЕ ВАСПИТАЧА СА УЧЕНИЦИМА У СРЕДЊОШКОЛСКИМ ДОМОВИМА
}

\author{
Недељко М. Милановић ${ }^{1}$
}

Anстракт: У раду су представљени резултати емпиријског истраживања које је имало за циљ сагледавање односа ученика према комуникацији коју остарују са васпитачем у средњошколском дому. Истраживање је спроведено на узорку од 67 испитаника и то 36 женског и 31 мушког пола. За потребе овог истраживања коришћена је дескриптивна метода - техника анкетирања. Анализирани резултати истраживања приказују да највећи број ученика осећа пријатност и опуштеност у комуникацији са васпитачем. Према мишљењу ученика, комуникација у средњошколским домовима се може унапредити организацијом радионица на тему вербалне и невербалне комуникације, већом посвећености васпитача комуникацији са ученицима и поседовањем више времена и стрпљења да саслушају ученике. Резултати истраживања приказују да ученици сматрају да васпитачи поседују ваљане вештине вербалне и невербалне комуникације и да је код васпитача заступљенија демократска комуникација од аутократске. Како би живот и свакодневно функционисање ученика у дому било позитивно и ефикасно, неопходно је да комуникација на релацији васпитач-ученик буде квалитетна, здрава и успешна.

Кључне речи: комуникација, васпитач, ученик, средњошколски дом.

Примљен: 09.01.2020.

Прихваћен: 22.01.2020.

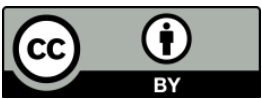

\footnotetext{
${ }^{1}$ nedeljko996@gmail.com,. Универзитет у Крагујевцу, Факултет педагошких наука у Јагодини, Мастер студент
} 